\title{
Sugar and slaves: The Augsburg Welser as conquerors of America and colonial foundational myths
}

\section{Julia Roth}

To cite this article: Julia Roth (2017) Sugar and slaves: The Augsburg Welser as conquerors of America and colonial foundational myths, Atlantic Studies, 14:4, 436-456, DOI: 10.1080/14788810.2017.1365279

To link to this article: http://dx.doi.org/10.1080/14788810.2017.1365279

曲 Published online: 29 Sep 2017.

Submit your article to this journal $\llbracket$

Џ Article views: 19

Q View related articles $\square$

View Crossmark data ¿ 


\title{
Sugar and slaves: The Augsburg Welser as conquerors of America and colonial foundational myths
}

\author{
Julia Roth \\ Center for InterAmerican Studies, Bielefeld University, Bielefeld, Germany
}

\begin{abstract}
In her 1883 collection of biographies of the most famous conquistadores of the Americas, Colombian writer Soledad Acosta de Samper noticeably included two German representatives of the Augsburg-based Welser trading company. Her depictions demonstrate that German finance and investment has been constitutive for the early colonial endeavor in the Americas of which the enslavement of Amerindians and the trade in enslaved Africans formed an integral part from the outset. This essay pursues a twofold aim: Firstly, it employs Acosta de Samper's account of the Augsburg traders as a lens for elaborating on the little-studied German activities in the Spanish colonies. Secondly, the essay is interested in how early colonial endeavors such as the Welser's have been serving as a showcase example for German colonial fantasies ever since. Both arguments refute the dominant discourse of the "late" or "insignificant" German role in the colonial enterprise, the transnational slave trade, and the trade in enslaved Amerindians. This essay will pursue and promote a perspective that focuses on the entangled histories and processes of conquest and colonialism, thus broadening the claim of the structural involvement of German-territorial actors such as the Welser company whose activities were transnational in scale to begin with. A relational entanglement perspective brings into view the transnational flows of capital, goods, people, and ideas; the essay thereby raises questions concerning the acknowledgement and confrontation of a German responsibility for colonization and enslavement.
\end{abstract}

\section{KEYWORDS}

German colonizers; Welser; German copper mine in Cuba; German conquest of Venezuela; German slave traders; German financing of conquest; German colonial fantasies; Soledad Acosta de Samper; Ambrosius Alfinger; Nicolaus Federmann

The Colombian journalist, novelist, historiographer, and defender of women's rights Soledad Acosta de Samper (1833-1913) was the first woman to write about the conquistadores, and also the first author to include the early German colonizers of the Americas. In her introduction to the Biografías de Hombres llustres ó Notables (Biographies of Famous or Notable Men), Acosta de Samper collected around 300 biographies of the most famous "discoverers," conquistadores, and missionaries to the Americas. In the section "discoverers," she emphasizes the decisive role the Welser traders from Augsburg and their representatives, so-called factors, played in the conquest of the Americas. Acosta de Samper traces the Welser's motivations for the conquest by reconstructing their routes 
to the most significant part of the German colonization in what is today Venezuela and Colombia. She writes:

Unfortunately, the initiated colony (of Venezuela) was only a year old, when emperor Charles V had to take the fruit from her to fill his royal till, emptied because of the wars he kept up against most of the European kings. With the objective to obtain the jingly money that a company of rich Flemish traders (the Rothschilds of the sixteenth century) offered him, brought them, as a feud of the crown, all the territory of Venezuela, from Cabo de la Vela to Maracapana, with the right to conquer the land, and under the condition to found two cities and three forts. They were under the mandate of a governor or adelantado who was nominated by the company that was called the Welzares or Belzares of Augsburg. ${ }^{1}$

[Por desgracia, apenas tenía un año de vida la iniciada Colonia [de Venezuela], cuando el Emperador Carlos $V$ tuvo á también sacar fruto de ella para llenar sus arcas reales, vaciadas por las guerras que sostenía contra la mayor parte de los reyes europeos. Con el objeto de conseguir el dinero sonante que le ofrecía una compañía de ricos comerciantes flamencos (los Rothschild del siglo XVI), cedió á éstos, como feudo de la corona, todo el territorio de Venezuela, desde el Cabo de la Vela hasta Maracapana, con derecho á conquistar en la tierra adentro, y con la condición de fundar dos ciudades y tres fortalezas bajo el mando de un Gobernador ó Adelantado, que nombraría a la compañía que llamaban de los Welzares ó Belzares de Augsburgo.]

Through the prominent inclusion of two early German conquerors in her book, Acosta de Samper's account hints at the German partaking in the conquest of the Americas: Southern German trading houses like the Fugger and the Welser played a central role as financers and traders during the economic expansion in and network building in and with actors in the Americas since the fourteenth century. ${ }^{2}$ Being one of the wealthiest and most influential traders of the Renaissance, the Welser company became an interesting trading partner for Emperor Carl V. who was financing the Spanish conquest through foreign investment. Enjoying privileges based on their financial support for the ruling houses, these companies gained great impact in the political proceedings of the then Holy Roman Empire of the German Nation(s) as financers and experts. ${ }^{3}$ Today, Germany is usually held to have played a comparatively insignificant role in the conquest of the Americas, in early colonialism, and in the transatlantic slave trade. However, the episode of the company of the Welser, and, to a lesser extent, the Fugger, during the early phase of the conquest reveals that German capital and expertise was indeed crucial for the colonial endeavor, even though German engagement might have been smaller in numbers than that of other European powers. Moreover, the Welser episode has been crucial with regard to German self-fashioning ever since, thus increasing the Welser's symbolic and epistemic impact to a larger extent than their actual historical influence might have been. This essay is particularly interested in this symbolic and epistemic significance for later German colonial discourses.

The use of the term "German" for the time period during which the Welser was active in the Americas is debatable since the German Reich was founded later. However, the different kingdoms, princedoms, etc., being part of the Holy Roman Empire of the German Nation (ruled by the Habsburg monarchy, Catholic Austria, and Lutheran Prussia), I refer to the "Germans" in accordance to numerous of my sources. ${ }^{4}$

This essay focuses on the entangled character of global interrelations based on the notion that German actors, capital, and ideas have from the outset formed an integral 
part of the conquest and colonization of the Americas. It pursues a relational perspective for a current reading of the Welser which highlights the transnational character of different actors beyond national borders and different regions, when it comes to colonization and the German involvement in the slave trade. Shalini Randeria has coined the notion of "entangled histories of uneven modernities" as a historical concept of transcultural relations. Due to its historical dimension and the attention to historically produced and persistent colonial asymmetries, her concept provides a helpful frame. ${ }^{5}$ The concept goes back to Sidney Mintz's elaboration on the history of sugar. ${ }^{6}$ Based on the idea of a "shared and divided" history, Randeria's notion of "entangled histories of uneven modernities" focuses on the intertwined but unequal interrelations and exchanges between the regions of the world, while accentuating that not only the colonizing countries had an impact to the colonized regions, but that the transfer has been happening vice versa as well, even so under structurally highly uneven terms. The concept aims at rendering problematic the notion that Europe/the West would have developed independently from the "rest" of the world.

Accordingly, rather than presenting a marginal and negligible aspect in the colonial endeavor as many studies still have it, a relational perspective reveals the ways in which the Welser have served as an example and reference for German colonial endeavors and fantasies ever since. Making the German participation in the colonization process visible enables another perspective on the German involvement in global entanglements and structures of inequality. Unlike dominant accounts of German history, which locate German colonialism solely in the "big" German colonies in Africa in the late nineteenth century, such a perspective shows that German actors, labor, and capital have formed an active part in the colonial process from the outset and opens the view toward transnational entanglements. In a second step, building on Susanne Zantop's work on German colonial fantasies, the essay examines examples of colonial fantasies coming up during the imperial-colonialist expansion of the nineteenth century in Germany. These fantasies were often based on foundational myths from the early phase of the conquest. In the nineteenth century in particular, the example of the Welser (and, to a lesser extent, the Fugger) served as such a powerful myth and as a reference point for those who supported colonialism and dreamed of a "place at the sun" for Germans.

\section{Germans in the conquest}

In accordance with Acosta de Samper's account, Charles V. financed the conquest with private capital. When in the early sixteenth century, it became probable that the Habsburgs would also inherit Spain, South German merchants, who maintained close relations with the Habsburg monarchy, saw their chance to profit from the expansion into the Americas. Already in 1508, the Welser owned large lands on the Canary island of Tenerife and soon a sugar plantation with a mill on the island of La Palma, thus becoming very active in the European sugar market. ${ }^{7}$ In 1519, the Welser and Fugger houses granted considerable large loans for the election of King Charles V. as emperor. ${ }^{8}$ In return, the traders were granted privileges - such as licenses for trading enslaved Africans and partaking in the conquest of certain American regions - hardly any other actor enjoyed. These privileges were fixed in the Contract of Madrid from 12 February 1528. Together with the 
Asiento contract of 28 March 1528 granting the Welser a secure colonial staging point in Venezuela, they are also being referred to as "Welser Contracts." ${ }^{\prime 9}$ By that time, the conquest of "Las Indias Occidentales" - as Europeans also called the Americas until the nineteenth century, referencing Marco Polo's term - was at its peak. Montezuma's realm in Mexico had already been overthrown, fueling heretofore-unimagined fantasies among the conquerors from Europe about riches through the discovered gold treasures. ${ }^{10}$ Meanwhile, the conquest of South America was just beginning.

Although the South American territories were actually closed to foreign colonial interests, the Welser company was allowed to conquer, re-colonize, and exploit large parts of what is today Venezuela and parts of Colombia. The company of Bartholomäus (V.) Welser senior (1484-1561) held the governorship of "Little Venice" (Venezuela) from 1528 until 1556. During this time, his governors carried out seven larger expeditions in the region, the so-called entradas, covering a distance of more than 20,000 kilometers. Several hundred (Christian) Europeans who set out to find local civilizations rich enough to be plundered usually carried out the entradas. The Welser are even referenced as creators of the myth of the gold city of El Dorado based on a Colombian legend in the sixteenth century. ${ }^{11}$ The German governors conquered Cundinamarca and founded New Granada. For the Welser, the colonial foundation provided a secure staging-post for their trade in the Americas, first under the governance of Ambrosius Alfinger (1529-1533), who in 1530 handed the authority over Venezuela in form of a letter of attorney to his vice governor Nicolas Federmann. Later governors were Georg Hohermuth von Speyer (1533-1540), and Philipp von Hutten (1540-1546). In what is today Colombia and Venezuela, the Welser built, or participated in, the foundation of several cities such as Coro Maracaibo and Bogotá under Alfinger. Until 1554, the Welser company exploited minerals at the Venezuelan coast, hoping to find great amounts of gold. When Federmann and Alfinger did not discover gold, they captured, enslaved, and sold Amerindian inhabitants. ${ }^{12}$ The assassination of Philipp von Hutten and Bartholomäus Welser (Vl.) junior in 1546 near Quíbor during an expedition in search for El Dorado terminated their governance of Venezuela. With the death of Charles V. in 1556, the trading rights expired. After the conquest was completed, the Spanish crown ended the private financing of the colonial project. ${ }^{13}$

The Spanish crown had hoped to gain the Welser financiers' support for the colonial holdings because the privileges the crown granted the Welser company for the conquest in the Caribbean region promised the Germans profits from various businesses, including the trade in enslaved Africans. As German Studies scholar Susanne Zantop emphasizes: "The wealthy financiers would thus help the Spaniards expand and secure their colonial holdings, while doing some colonizing and profiteering on the side. ${ }^{14}$ Since the conquest was an insecure endeavor, the Welser were granted the "safeguarding through a net of rights and contracts." ${ }^{15}$ Most importantly, this "safeguarding" consisted in receiving the monopoly of the trade in enslaved Africans, which provided them the most profitable source of income during their involvement in the conquest. ${ }^{16}$ Other sectors the Welser were participating in and profiting from, such as the sugar production and copper mining industries, also relied on enslaved labor. Hence, from the outset, a broad range of investment, production, and trading activities accompanied the Welser's conquering activities in the Americas. 


\section{Products and profits: The Welser in the Caribbean}

Despite a growing number of studies and publications dealing with the Welser and the Fugger and other early German colonizers in the conquest of the Americas, the aspect of their partaking in the transnational slave trade is seldom elaborated on. ${ }^{17}$ In an early study of 1962, economic historian Enrique Otte claimed that "the chapter on the slave trade is one of the least satisfying of the hitherto existing research on the Welser," ["(d)as Kapitel über den Sklavenhandel ist eines der unbefriedigensten der bisherigen Welserforschung."] and his dictum can still be considered paradigmatic for the dominant German discourse on the Welser. ${ }^{18}$

In 1526, the Welser governors Jörg Ehinger and Ambrosius Alfinger founded an overseas trading establishment in Santo Domingo on the island of Hispaniola (today Dominican Republic and Haiti). Already in 1523, the trading house of the Welser had started to grow sugar cane in Santo Domingo for producing sugar, the first colonial mass product of the global economy. ${ }^{19}$ In 1532, the company purchased the sugar mill Santa Bárbara in the department of San Juan de la Maguana through the Welser's overseas agent Sebastian Renz from Ulm for the price of 3427 Pesos, 202 Arrobas sugar, and 4 slaves. ${ }^{20}$ With 11 kettles, Santa Bárbara was one of the largest mills on the island, where sugar production was becoming the main industry. ${ }^{21}$ In general, the work on the sugar mills was carried out by enslaved Africans, and the list of inventories of the sugar mill Santa Bárbara provides insightful proof thereof. ${ }^{22}$ The bill of sale for the sugar mill Santa Bárbara from 1530 lists "a gin trap for the 'negros' with chains." ["(U)n cepo de los negros con su cadenado $y$ telera." ${ }^{23}$ In contrast to some of the animals of the mill, the enslaved African workers are not mentioned by name. Between "the following oxes" which are listed by name, and "the following beasts" ["los bueyes siguientes" and "las bestias siguientes"], which are partly listed by name, the bill also lists "up to 14 'negros' and other absent ones, which would be up to 16." ["La gente de negros que hay en él, hasta catorze negros presentes e otros dos absentes, que serían hasta diez e seys." ${ }^{24}$ On the one hand, such listings provide evidence for the well-known, but often neglected fact that enslaved African workers constituted an integral part of the sugar industry in the Caribbean long before enslaved labor became the backbone of the US-American tobacco and cotton industries. On the other hand, listing them in the same category as the animals points at the dehumanized and disenfranchised status of the enslaved workers. As mentioned above, as part of the privileges granted to them by the Spanish crown, the Welser held the monopoly for the import of slaves, a much-needed unpaid workforce after the extinction of the autochthonous populations of the Antilles. ${ }^{25}$ Already in 1526, Heinrich Ehringer and Hieronymus Sailer had bought licenses for the trade in enslaved Africans from the Genovese Tomás and Domingo de Forne (for 85 enslaved Africans licensed by the governor Lorenzo de Gorrevod), and in 1527 from the Spanish Antonio de Medina and Diego de Zárate licenses for a total of 155 enslaved Africans. Most of the licenses were soon to be re-sold. ${ }^{26}$ A contract from 12 February 1528 granted them the license to import 4000 enslaved Africans to the Americas over the following four years. ${ }^{27}$ For this license, the Welser company had paid the Spanish crown 20,000 ducats to be paid back over four years. In turn, they were freed from all further tolls for sale or import, which opened for them a profit opportunity of 80,000 ducats. ${ }^{28}$ Besides the trade in luxury goods such as cloths, sugar, gold, pearls, vine, and medical products like guaja wood (a 
treatment against syphilis) and the increasing export of sugar, the slave trade provided the company's major source of income. ${ }^{29}$

For the years between 1532 and 1538, Otte bemoans an "imprecise state of sources" ["ungenaue Quellenlage]" regarding the number of enslaved Africans imported by Germans. $^{30}$ The only documents he could find are the fragmentary and incomplete Dominican Almorjarifazgo lists which state 10 transports of enslaved Africans by Germans, 2 at a time for the years 1532, 1533, 1537 and 1538, 1 for 1534 and $1536 .^{31}$ Otte estimates that in each case supposedly 150-200 enslaved Africans were "delivered" to the Americas. ${ }^{32}$ He further mentions the decree of Spanish Empress Isabella from September 1532, in which she permits the Germans to "again send their overseas governors to America in order to transfer and sell the rest of the 4,000 slaves." ["(die Kaiserin Isabella stellte den Welsern die Erlaubnis aus,) erneut ihre Faktoren nach Amerika zu senden, um den Rest der 4.000 Sklaven zu überführen und zu verkaufen."] ${ }^{33}$ Other known licenses he lists are the ones from 30 May, 1535, by the Emperor Charles V. to Heinrich Ehinger and Albert Cuon (who was not a Welser) for 200 enslaved Africans as compensation for their pastel and saffron treaty, which they sold to Juan Glavarro already on 21 June, and in July 1529 a license for the export of 800 slaves to the Welser (whom they, again, re-sold). ${ }^{34}$

Besides the use of enslaved labor as part of their sugar production, the Welser company also invested and participated in the exploitation of minerals such as silver in the Mexican mines of Sultepec and copper discovered around 1538 near Cotuy. ${ }^{35}$ Copper became a much-sought-after mineral in the Caribbean colonies for the pots and pans needed for the booming sugar production ${ }^{36}$ Up until this point, these pots were imported from Europe, in particular from Nuremberg. When copper mines were discovered in Cuba, the Fugger and Welser saw their bargain here as well since they had experience in mining. The Spanish crown was eager for the export in experienced miners and, again, granted the agents of the Welser company these privileges. Arriving in Cuba in 1540, the patrician and mining expert Johann Tetzel, to whom German historian Theodor Gustav Werner refers as "the first 'montane entrepreneur' of the 'New World,'" bought the copper mine El Cobre near Santiago de Cuba with the financial support of Lazarus Nürnberger (from whom he received 500 gulden in 1546) and others. ${ }^{37}$ Tetzel made efforts to find new ways of extracting copper and attempted to return to Cuba with mining experts. Therefore, in the asiento of 11 January 1546 on the exploitation of the copper mines in Cuba, signed in Madrid, Charles V. granted "Hans Tetzel from Nürnberg" the right to start running "first 10 and later more" copper mines and to erect the necessary buildings. ${ }^{38}$ Furthermore, during the first 10 years the crown freed Tetzel from customs for the material and equipment necessary for the mines and for the produced copper. ${ }^{39}$

German capital unquestionably had a decisive impact during this early epoch of European colonization. Cuban historians Álvarez Estévez and Guzmán Pascual highlight that the "sense and orientation" of the German traders furthermore helped to facilitate the import of many German products - such as equipment for copper mining or, later, for building railways - to the Cuban market. ${ }^{40}$ Their economic and financial power further enabled them to establish close contact with the colonial government in Cuba as well as with the highest levels of politics and society on the island, granting them special privileges such as trading licenses, good conditions for the purchase of land and mills, and even privileged citizenship rights. ${ }^{41}$ Regardless of the small role and episode of Tetzel's activities in Cuba, Álvarez Estévez and Guzmán Pascual see the arrival of Tetzel and his 
team as the island's first contact with international finance capital; they argue that Tetzel's limited exploitation of these copper mines which started in 1530

contributed to the fact that Cuba found itself [...] for the first time in contact with the big financial powers of the world, represented by the German houses of the Fugger and the Welser of Augsburg, of the Ehingers of Constance, of the Hochstaetters etc. ${ }^{42}$

In a similar way, German historian Theodor Gustav Werner considers the Tetzel mine in Cuba and the implementation of such enterprises in general as the "seed" for an industrial development in the Americas which required an entrepreneurial spirit, experience, good planning, equipment, and production means as well as a respective number of workers and enslaved unpaid workers. ${ }^{43}$ German historian of slavery, Michael Zeuske, emphasizes that by ensuring the factual monopoly of the captive and slave trade between Africa and the Americas in 1528, the Welser actually exercised "the first monopoly control of the Atlantization between the West African and the Caribbean sugar enclaves." ${ }^{\prime 4}$ He argues that Germans from different locations actively participated in the trade in enslaved workers, bringing many traders "wealth and standing." ${ }^{45}$ According to Zeuske, such German slave traders contributed to "new stages of capitalism" marked by the intertwining of mass slave trade and financial, scientific, technical as well as technological dynamics. ${ }^{46}$ Thereby, the influence of most of the magnate merchants and bankers shifted increasingly from Africa to the Atlantic and the Americas. German colonial engagement in the Americas did, of course, not end with the Welser episode - there are numerous other examples of German traders making profit in the region. ${ }^{47}$ These investments usually included the exploitation of slave labor, and German merchants continued to be actively involved in the trade in enslaved African workers. ${ }^{48}$

In addition to examining the national dimension of involvement in the slave trade, which is still rarely done in German public discourse an inter-relational focus brings into view the transnational flows and entanglements of capital, goods, people, and ideas. As Zeuske shows, it is worthwhile to analyze the processes of conquest, colonization, and enslavement also as structural, relational, and entangled phenomena, not solely as national endeavors. A relational perspective helps to make more visible also the impact of actors such as the Welser, who were not citizens of one of the major colonizing nations and are therefore often marginalized or omitted in historical accounts on or representations of the period. The newly built "Fugger und Welser Erlebnismuseum" (Fugger and Welser Adventure Museum) in Augsburg provides a recent example of a revision of this tendency. The museum presents Augsburg as a metropolis of European trade and the Fugger as the "first global players" as can be read on a stand-up display at the museum's entrance. The partaking in the trade in enslaved Africans and the enslavement of Amerindians is briefly mentioned on two displays of the exhibit, but there is no mentioning of the role of the exploitation of slave labor for the increase in affordable luxury goods in Europe and the accumulation of wealth while the exhibit as a whole follows a positivistic representation of the Fuggers' and Welsers' activities as a progress and success story, which each year still attracts numerous tourists to the Bavarian town. The magazines by the Augsburg tourism agency available at the museum praise the Fugger and Welser as "geniuses of commerce," ${ }^{49}$ these publications depict Anton Fugger as "the wealthiest man of the world" and present him as a role model for doing business today." ${ }^{10}$ 
While today the Welser and Fugger are thus romanticized as progressive first "global players," their activities historically functioned as a romanticized colonial foundational myth and as an important reference point for later colonial endeavors and cultural texts. The Welser's colonial involvement as financers, factors, mining experts, and conquerors has served as an important trope in numerous German self-narrations on colonial and imperial power until later phases of German colonial and imperial expansion and came to function as a model for later colonial German engagement.

In a cursory glance at the discourse about the German colonizers, the following section thus focuses on the interpellation and interpretation of the Welser enterprise by the friar Bartolomé de Las Casas in the sixteenth century and by the writer Soledad Acosta de Samper in the nineteenth century as two very opposite readings and as discursive landmarks of the Germans' activities in the colonies. A relational perspective proposes to digress from the focus on nation states, on only the "biggest" colonial players, and on one-dimensional (moral) evaluations of such historical actors. It shifts the focus instead toward the discursive effects their representations had as well as for their impact for uncovering entangled histories beyond national, cultural, and ideological boundaries. Both Las Casas' and Acosta de Sampers' text reference the entwined character of different histories (for instance by pointing at the active German partaking in the conquest) and simultaneously justify European colonialism and persistent unequal power structures, since both do not question the righteousness of colonial domination and support the missionary (in Las Casas' case) and imperial (in Acosta de Sampers' case) project.

\section{Black legends and colonial foundational myths}

When it comes to the reception of the German partaking in the conquest, German historian Jörg Denzer makes out "two major trends" initiated by the early chroniclers that have marked the interpretation of the epoch of the German conquerors until today: first, a rather positive evaluation of the German enterprise as introduced in the chronicles by the Spanish chronicler Oviedo y Valdés, and, second, a tradition of historiography coined by Dominican friar Bartolomé de Las Casas' polemic referred to as the German Black Legend. ${ }^{51}$ This tradition depicts the Welser epoch as the darkest chapter of the Spanish conquest of the Americas, and it was employed anew in different historical contexts such as the Nazi dictatorship. ${ }^{52}$ Originally, the Black Legend (leyenda negra) referred to the negatively connoted cruel behavior of the Spanish conquerors and colonizers in the Americas as described by Las Casas. In his Brevísima relación de la destrucción de las Indias (An Account, Much Abbreviated, of the Destruction of the Indies, 1542), Las Casas had indicted the Spaniards for their brutality against the Amerindian inhabitants. Actually being addressed to the Spanish crown in order to stop the crimes the Spanish conquerors committed against the Amerindian populations, Las Casas' account has become one of the most controversial texts concerning the conquest of the Americas and its aftermaths. ${ }^{53}$

Notably, in line with this argument, defenders of a pro-Spanish position have referred to Las Casas' Account, Much Abbreviated, by promoting the Germans as the most brutal colonizers, regardless of the predominating accusations of the Spanish atrocities in the colonies. ${ }^{54}$ The so-called German Black Legend Las Casas interpellates in this argumentative piece served to blame the Germans for having been the worst conquerors, and indeed more cruel than the Spaniards. Las Casas further used the arguments of his book in the 
famous theological and philosophical debate of Valladoid he had with Ginés de Sepulveda on whether the indigenous population had souls and thus should be granted human rights. The Black Legend is based on Las Casas' depiction of the Germans in his chapter "On the kingdom of Venezuela" in an equally accusatory manner in the same text as "those German, or animal, tyrants," 55 and he denounces the Germans' capturing and enslavement of the Amerindians as extremely brutal. ${ }^{56}$ Aiming at convincing the king to become active against the cruelties committed in the Americas, Las Casas' text is highly polemic and full of exaggerations; for instance, he uses extremely high numbers such as of victims of the colonizers' cruelties. While Las Casas dedicated a relatively small part of several paragraphs to the German participation in the conquest, Acosta de Samper's Biographies of Famous or Notable Men three centuries later gave a more differentiated view of the German colonizers. ${ }^{57}$ Acosta de Samper's depiction of the Welser draws a manifold picture of the Augsburg colonizers and traders in the Americas. She describes Ambrosius Alfinger, the Welser governor and colonizer of parts of what is today Venezuela, as a monstrous creature devoid of human feelings. The way she depicts Alfinger seems to be in line with Las Casas' one-sided depiction of Germans, Acosta de Samper compares Alfinger to the Hun ruler Attila and portrays him as a monster who treated the Amerindian with pure cruelty when claiming: "Fortunately for the indigenous of the plateau of Bogota, it was not their fate to have Alfinger as their first discoverer, since this new Attila would have destroyed them." ["Felizmente para los indígenas de las mesetas de Bogotá, no tocó Alfinger ser su primer descubridor, pues aquél nuevo Atila las hubiera dejado asoladas." ${ }^{58}$ Already in her introduction to the book, Acosta de Samper depicts Alfinger in negative terms, particularly in comparison to her appraisal of Christopher Columbus' "heroic" achievements as "this soldier of faith and knowledge":

the first is DISVCOVERY. It necessarily begins with Columbus' life and continues with the narration of the most notable discoverers, from OJEDA to this monster that was called Alfinger. ${ }^{59}$

[ese soldado de la Fe y de la Sabiduría. [...] La primera es el DESCUBRIMIENTO. Ésta empieza por necesidad con la vida de Colón, y continúa con la relación de los descubridores más notables, desde OJEDA hasta aquel monstruo que se llamó Alfinger.]

However, in contrast to her negative description of Alfinger as a brute monster, which seems to cater to the German Black Legend, Acosta de Samper describes Nicolaus Federmann in essentially positive terms, thereby pointing at the diverse and manifold characters and ways of behavior of early German conquerors:

It was Nicolás de Federmann, a man of such good and courteous manners, that the chroniclers reference that he was never heard to utter broken words, and he was so friendly, compassionate and merciful with his inferiors that these adored him. He has never been accused of being grabby, nor cruel, and his enemies could never mention a bloody or pervert deed by him. ${ }^{60}$

Acosta de Samper refers to Federmann's ambition in the conquest and his consequent disobedience to his governor Alfinger in a more balanced tone than Las Casas and others. ${ }^{61}$ Her depiction illustrates that German conquerors were, for one, as common as conquerors of other origins and thus deeply intertwined with the colonial endeavor, including the trade in slaves. ${ }^{62}$ Secondly, Acosta de Samper's portraits show that their conduct in the colonies also differed just as much as among the conquerors of other groups. Besides their necessarily partial and context-bound viewpoints, both Las Casas' and Acosta de 
Samper's texts provide insightful sources for the active involvement and participation of German financiers, merchants, adventurers, mercenaries, and slave traders in the colonization and exploitation of the Americas already in the sixteenth century. By portraying them as presenting a range of characters, Acosta de Samper's account suggests a certain normality, or even banality of the German conquerors who were neither monsters, nor heroes. Acosta de Samper's portraits hence contradict the aforementioned widespread blaming of the German Welser traders as the worst conquerors of the Americas in order to deviate attention from Spain based on Las Casas' account. A relational perspective which focuses on the entangled character of global interrelations, as I would like to promote for a current reading of the Welser, brings a more complex picture into focus. Rather than making a moral statement, such a perspective seeks to uncover the ways in which German actors, German capital, and German ideas have been part and parcel of the European colonial expansion into the Americas from the start, and the Welser continuously served as a crucial point of reference for colonial endeavors, as the following section demonstrates. They thus represent a showcase example of the entangled histories of different actors, spaces which helped producing uneven structures or, following Randeria and Conrad, "modernities." A respective relational approach implies that, on the one hand, German actors, ideas, and money formed an active part in colonialism since the sixteenth century. On the other hand, such a focus reveals that, vice versa, the Americas were also constitutive for European, and also German, wealth, political, economic, and epistemic influence and expansion as well as for self-narrations and projections concerning colonial power. Today, the partaking in the colonial enterprise is still mostly played down in German public discourse, particularly after the horrible crimes committed by Germans in the name of imperialism and racial superiority during the Nazi regime. The conviction to represent a more "progressive," "developed" culture and political system and be in possession of superior forms of knowledge, civilization, religion, etc., persists, and is often justified precisely with the argument of the presumed absence of a "real" colonial history (the Nazi dictatorship excluded). Examining the Welser from a relational point of view thus serves to shift the focus to the continuities of colonial/modern engagement in and with the colonies as a structural (rather than exceptional) phenomenon, as a view on the discursive site of the nineteenth century illustrates.

\section{The Welser as nineteenth-century German colonial foundational myth}

Particularly in the nineteenth century in the context of European imperial colonialism, the Welser episode has served a completely opposite function to that of the Black Legend, transforming the Welser into heroic figures onto which foundational myths of German eligibility as conquerors and later colonial fantasies could be projected. These myths reveal another decisive aspect of the impact and the discursive function of the earlier German conquerors. It is characteristic for German historical and social discourse that, while the crimes of the Holocaust are being dealt with extensively, little attention has been paid to the entanglements and continuities of racist and colonial practices and politics since 1492. ${ }^{63}$

In the years 1770-1870, colonial fantasies gained momentum in German territories. It was a phase marked by the re-emergence of two thematic strands within colonial discourses: on the one hand the narrative of the failure of the Welser's enterprise, and, on 
the other hand the emphasis on their violent behavior as fueled by accounts such as Las Casas' which led to the German Black Legend. These strands were increasingly complemented with narratives that rejected the guilt and the formation of a German peculiarity. Zantop describes this phase as being marked by a "national character" related to a "distinct colonial cult." 64 Following Zantop, particularly the notion of the "missed opportunity" and the lack of larger colonial possessions of colonial power and wealth as incorporated by the Welser functioned as a basis for new German dreams and ambitions, thus serving first and foremost as substitute practices rather than as excuses for committed colonial brutalities: "not so much as an ideological smokescreen or cover-up for colonial atrocities or transgressive desires, but as Handlungsersatz, as substitute for the real thing, as imaginary testing ground for colonial action." 65

In accordance with such a perspective, the Welser myth provided a sort of foundational myth of German colonial fantasies. References to the Welser episode can be traced continuously in German discourses of colonialization, for example, when a new competition for the Caribbean islands was under way in the late eighteenth century, Zantop makes out a number of German texts, reports on the political situation, and dramatic plays expressing colonial fantasies. ${ }^{66}$ It seems noteworthy that these texts often make reference to South America, even though German colonial endeavors of that time focused on Africa and the Pacific. On the basis of popular literary, dramatic, journalistic, and political texts as well as children's books, Zantop's study demonstrates how references made to the early German conquerors and colonizers in these texts became a sort of "origin myth" or "foundational myth" for German colonialism. Zantop also shows that counter-narratives, which were critical toward the colonial and imperialist spirit, were not broadly received. Examples of such counter-narratives are the poem "Vitzliputzli" (1848) by German poet and dramatist Heinrich Heine or the famous long poem "Die Berlocken" (The Trinkets, 1881) by Swiss novelist and poet Gottfried Keller. Politically, both Heine and Keller remained marginal figures, "who could not defend themselves against the wave in popular writings that catered to psychic needs and not to reason or understanding and accommodated the desire for superiority, control, and possession." ${ }^{167}$

Tellingly, in an exemplary manner for the zeitgeist at the peak of German imperial and nationalist-fascist expansionism, the introduction to the 1938 publication Deutsche Konquistadoren in Südamerika (German Conquerors in South America) includes a reprint of Nicolaus Federmann's Indianische Historia. The motto to this book is an appraisal to the "noble German blood" in form of Johann Filchardt's 1573 poem "Ernstliche Vermahnung an die lieben Teutschen" (Serious Exhortation to the Dear Germans). German historian Arnold Federmann's introduction is titled "Forgotten Germans" and praises the Germans - and the Welser and Fugger in particular - as important patrons first of the trade with Portugal and Spain, and, later also as sponsors of the "journey West" and the conquest of Venezuela and parts of Ecuador. ${ }^{68}$ He laments, however, that while Columbus, Pizarro, or Cortés are well-known, the names of these German conquerors are hardly mentioned:

It thus remained unknown to the widest German circles that Germans not only took great part in the journeys of the Spanish and Portuguese to the East Indian territories, but that the Germans played the main part also in the allotment of Venezuela. ${ }^{69}$

He thus dedicates the book to the endeavor to make up for this "injustice done to the German names through the concealment even if it may be only silence." ${ }^{70}$ How much 
this edition is appropriated to the nationalist spirit of the Nazi dictatorship becomes even more obvious in the following paragraph, which draws a completely unrealistic picture of a German unity or character of the time of the Welser: "May from now on remain unforgotten in the conscience of the people what these Germans some day achieved during yearlong campaigns of conquest, daily endangering their lives - in the honor of themselves and the German name!" ${ }^{71}$ Even Adolf Hitler referred to the Welser and instrumentalized them for his endeavor to create a "new Germany" in Brazil in 1940, by arguing "the Fugger and Welser have had their possessions here."72

Notably, while in Nicolaus Federmann's account only the enslavement of captured Amerindians is mentioned, in his introductory description of the conquest of Venezuela, Arnold Federmann extensively describes the transatlantic trade in enslaved Africans. He refers to the privileges granted to the Welser in the contracts of 1528 , including,

that the owner of privileges should have the right to import 4,000 negro slaves to the West Indian colonies and sell them for no more than fifty ducats per negro. [...] The more frail characters among the conquerors and first colonists participated with pleasure in the slave trade or squeezed their bondservant Indians through excessive work. [...] The drop out of Indian work forces was now in these American colonies substituted by negro slaves with which there was a roaring and lucrative trade. ${ }^{73}$

[daß die Privileginhaber das Recht haben sollten, 4000 Negersklaven nach den Westindischen Kolonien einzuführen und für nicht mehr als fünfzig Dukaten pro Neger zu verkaufen. [...] Denn die anfälligen Charaktere unter den Konquistadoren und ersten Kolonisten beteiligten sich selbst gerne am Sklavenhandel oder preßten ihre leibeigenen Indianer durch übermäßige Arbeit aus. [...] Der Ausfall an indianischen Arbeitskräften wurde nun in diesen amerikanischen Kolonien unbedenklich durch Negersklaven ersetzt, mit denen man einen schwunghaften und gewinnbringenden Handel betrieb.]

Arnold Federmann's framing of Nicolaus Federmann's account demonstrates that while many Western European writers appropriated the Americas in cultural texts for different interests, for many Germans, these territories served the specific function of making up for a missed opportunity and a loss. This loss could be overcome through new efforts serving the construction of a Western superiority, or Occidentalism. As Zantop emphasizes:

The New World's Southern hemisphere was not only the first object of German colonial desire, it remained the German colonialist dream even after the German Empire actively supported settlement in Africa. The continued fascination with things South American [...] produced what I would call in analogy to Said's Orientalism, a German Occidentalism. ${ }^{74}$

Colonial activities in South America and Occidentalist projections thereof were omnipresent in German national self-fashioning. Postcolonial approaches and decolonial activism are nevertheless only slowly gaining momentum in German academic and political discussions. Respectively, it remains symptomatic for the German historic discourse to play down the colonial periods as well as the intellectual colonization of and implementation of epistemic Occidentalism in the Americas in which Germans played indeed a decisive part. ${ }^{75}$ Similarly, for a long time, little work has been done on the German involvement in the slave trade and the profits Germans made from enslaved labor. However, in recent years, the amount of singular events and projects addressing German colonialism and its legacies began to increase. ${ }^{76}$ As the mentioned examples of German colonial activities 
illustrate, structural forms of German colonial engagement provide a rule rather than a negligible exception.

\section{Outlook: Competitive memories and claims for reparations}

Acosta de Samper's two very different portraits of early German conquerors of the Americas first and foremost show that German conquerors were as common as conquerors of other origins and that they were also structurally involved in the colonial endeavor and the trade in slaves. Acosta de Samper's depictions illustrate that the German colonizers, just like the colonizers of all other nationalities, participated in, profited from, and also failed in the colonial enterprise and the slave trade. Secondly, in contrast to earlier, more generalizing depictions, her portraits show that the Germans' conduct in the colonies cannot be generalized, but that different colonizers behaved very differently, just like the conquerors of other groups.

From a relational perspective, Germans have been no exception, neither as latecomers nor as negligible actors, regardless of the number, size, or duration of actual German colonies. The case of the Welser shows that neither "Western" nor German wealth and "modernization" developed independently from other world regions. On the contrary, Western expansion and economic and financial growth were highly dependent on the exploitation of the colonized spaces, the labor of the colonized, the resources of the colonies, and imported enslaved work force. Since an entanglement perspective focuses on the structural dimension(s), it shows the ways in which German capital, goods, knowledge, and ideas have been involved in colonial expansion at least since the Welser's participation in the conquest of the Americas. Furthermore, it illustrates that the Welser have played a central part in the transatlantic slave trade and they profited from resources and luxury products produced by slave labor. From such a relational perspective, unequal global entanglements and persistent asymmetrical colonial power structures can be examined not as a recent phenomenon, but as having been a reality and a structural fact for more than 500 years. Situating German colonialism only in the nineteenth century is just part of the story. The perspective this essay proposes brings the interrelations and continuities into view and shows how German actors, capital, and knowledge have been part and parcel of colonization and the slave trade. German wealth was based on the exploitation of the resources and (cheap or unpaid/enslaved) labor in the colonies and was thus part in the production of global colonial inequalities that partly persist and are revived until today.

Furthermore, up until the culmination of racist imperialist crimes during the Nazi dictatorship the foundational myths of earlier conquerors like the Welser have fueled German colonial fantasies and the desire to make up for the "missed opportunity" of not having played a more significant role in the colonial contest. It is thus time to resuscitate these silenced memories and the claims for reparation and decolonization related to these memories and take responsibility for the German participation in enslavement, oppression, exploitation, and genocide. As German journalist and ethnologist Wolfgang Lieberknecht, for instance, puts it:

The slave trade, for which the Europeans were responsible, had of course been abolished when the German Reich was founded. But in the past centuries, Germans participated in the activities of the different European slave trading nations [...]. And it has, like most 
other European countries, not produced a movement for the abolition of the slave trade [...]. Thus, there are good reasons to ask also in this part [of the world] for the historical-moral responsibility for the slave trade and for the necessary consequences. ${ }^{77}$

Seen from this angle, later German colonial, imperial, and finally fascist engagement can no longer be treated as solely an outcome of the nineteenth-century European imperialist expansionist spirit isolated from earlier proceedings, interrelations, and continuities. Rather this spirit can also be read as a perceived late chance of making up for continuously disappointed dreams. Currently, an increasing number of activists and critical scholars in Germany confront this neglected part of history. One of their claims are reparations for the German genocide of the Nama and Herrero in what is today Namibia, and for stopping the denial of a meaningful German colonial history before the Holocaust. ${ }^{78}$ Others address persistent racist street names and the government's plan of a museum called Humboldt Forum, which shall contain collections received under questionable conditions from colonized spaces. Against the backdrop of the marginalized long history of German colonial practices and fantasizing, these claims appear in a different light as well.

\section{Notes}

1. Acosta de Samper, Biografías de hombres ilustres ó notabes, 79. My translation.

2. The Welser was an important trading house provided with international links and lots of capital. The company was therefore involved in political contexts and provided for example public housing in Augsburg. The Welser and Fugger families developed the first balance sheet and used their expertise to oversee the financial transactions for the Roman Curia, or Council, gaining the family increasing political power. These activities in combination with maintaining strong business relations to the Habsburg Royal Family and owning trading centers in Venice and Nuremberg helped to further increase the family's wealth and political influence. Over time, the Fuggers functioned as bankers for popes, emperors, and kings while maintaining their interests in the trade of goods, such as copper and newspapers.

3. While the English translation uses the singular form (Holy Roman Empire of the German Nation), in German, "nations" is used in the plural form (Heiliges Römisches Reich Deutscher Nationen).

4. See for example Las Casas' account from 1542 who uses the term "German" in a general, allencompassing way, referring to the conquerors (particularly Alfinger) from the German-speaking regions. See also the section on Las Casas in this essay.

5. Randeria, "Entangled Histories."

6. Mintz, Sweetness and Power.

7. Zeuske, Handbuch Sklaverei, 508.

8. The Fugger, another wealthy Augsburg-based trading enterprise, received contracts securing them the use of the American colonies and the rights to exploit the Spanish copper and quicksilver mines as an insurance and acquittance for their credits. Products from the transnational slave trade entered the trading network of the Fugger and the Welser alike. However, unlike the Welser, the Fugger's actual time in the Americas was limited: their endeavor to conquer what is today Chile was soon abandoned due to the region's less central geographical position and Pizarro's influence in the Andean region. Denzer, Die Konquista, 55.

9. Denzer, Die Konquista, 28.

10. Ibid., 12.

11. Ibid., 14-15.

12. Ibid., 20-24.

13. Ibid., 26.

14. Zantop, Colonial Fantasies, 19-20.

15. Denzer, Die Konquista, 53. 
16. Lieberknecht, "Der Sklavenhandel." The original reads: "Wir geben euch Erlaubnis, dass ihr oder wer eure Vollmacht hätte, 4000 Negersklaven (aus Afrika), davon wenigstens ein Drittel weiblichen Geschlechts, nach den genannten Inseln (Haiti und Puerto Rico) und dem Festland bringen und dort verteilen könnt." [We give you permission that you, or who might have the letter of attorney, to bring 4000 negro slaves (from Africa), of which at least one third female, to the mentioned islands (Haiti and Puerto Rico) and the mainland and distribute them there.]

17. See, for example, Otte, "Die Welser;" Schmitt, Konquista als Konzernpolitik; Simmer, Gold und Sklaven; Denzer, Die Konquista. For a particular focus on the enslavement of Amerindians, see Schmitt, Konquista als Konzernpolitik and Simmer, Gold und Sklaven.

18. Otte, "Die Welser," 128; footnote 85. My translation.

19. Mintz, Sweetness and Power; Ortíz, Cuntrapunteo Cubano.

20. Arroba (from Arabic al-rub) is an old Spanish weight unit still used in Mexico equal to about 25 pounds (or 9.5 kilograms). It is also an old Portuguese unit of weight still used in Brazil equal to about 32 pounds or 12 kilograms ("Arroba," Merriam Webster; "Arroba," Dictionary.com).

21. Otte, "Die Welser," 126.

22. The following numbers are based on the list elaborated on by Otte ("Die Welser"). Otte points out that the original price was "16 enslaved Africans" ("Die Welser," 126).

23. See Otte's transcript in "Die Welser," 153. My translation.

24. Ibid., 154. My translation.

25. Ibid., 132. According to Otte, the Welser were already involved in the slave trade, when Charles V. offered them to take over the commerce. The first transport in enslaved Africans reached Santo Domingo in December 1528 with 250 enslaved Africans on board.

26. Ibid.

27. Ibid., 133. Otte elaborates on the "advantageous sales and payment conditions" for the German traders, for instance, the highest price per enslaved. He mentions acts of resistance by the American subjects against the privileges for the Welser.

28. Denzer, Die Konquista, 53.

29. Otte, "Die Welser," 139. Otte's study demonstrates that the trade in enslaved Africans formed an integrated part for the German traders' colonial conquest. According to Otte, Lazarus Nürnberger also traded in slaves and at the end of 1544 bought a license for 25 enslaved Africans whom he thought to deliver to America from the entrepreneurs Jácome and Juan Bautista Botti. In April 1544, Nürnberger let the register of the Casa de la Contratación confirm him to buy twenty male and five female slaves at the Cape Verde Islands and ship them to the Americas.

30. Ibid. My translation.

31. Ibid. The almorjarifazgo was a tariff applied to exports and imports of goods imposed by the governor Lope García de Castro.

32. Ibid. Otte emphasizes that these numbers do not coincide with the declaration of the Audiencia Real of Santo Domingo from the end of July of 1535.

33. Ibid., 140. My translation. Following Otte, the fiscal of the Indian Council, Juan de Villalobos, criticized the quality of the enslaved Africans delivered by the Germans.

34. Ibid., 143.

35. Denzer, Die Konquista, 50.

36. Werner, Das Kupferhüttenwerk, 20.

37. Ibid., 19.

38. Ibid., 317. The asiento in the history of slavery refers to the permission the Spanish government gave to other countries between the years 1543 and 1834 to sell people as slaves to the Spanish colonies.

39. Ibid., 471-472.

40. Álvarez Estévez and Pascual, Alemanes en Cuba, 23.

41. Ibid., $24,25$.

42. Ibid., 44.

43. Werner, Das Kupferhüttenwerk, 465. 
44. Zeuske, Handbuch Sklaverei, 504.

45. Ibid., 512.

46. Ibid., 514 .

47. The German administration of the island of Tobago from the 1630 s until 1659 and a commercial settlement in St. Thomas from 1685 until 1731 provide further examples of German activities in the colonies worth mentioning. Other endeavors, such as the attempt of Friedrich Wilhelm and his successors to purchase or occupy islands like Tobago, St. Croix, or St. Eustache for their trade in enslaved workers, failed. The Bavarian-Dutch and French-Bavarian joint colonial projects in Guyana (1664) were not concluded, neither was the colonial contract between the Duke of Hanau and the Dutch West-Indian Compagnie over a colony referred to as "Hanau-Indien" (Hanau-India, 1669), located between the Orinoco and Amazonas rivers (Zantop, Colonial Fantasies, 33). In the seventeenth century, inspired by Dutch traders, the elector of Brandenburg Friedrich Wilhelm participated in colonial endeavors on the African West coast. An expedition in 1681 to the so-called Gold Coast resulted in the foundation of the Brandenburg-African Compagnie (brandenburgisch-afrikanische Kompagnie) for the triangular overseas trade with West Africa, which held the Brandenburg monopoly over the African trade in pepper, ivory, gold, and enslaved Africans for 30 years. In 1687, the Compagnie built the fort Groß-Friedrichsburg and a settlement in Arguin, both of which primarily served for the trade in enslaved Africans. During its existence (between 1450 and 1867), the company sold about 19,000 enslaved Africans who had survived the Middle Passage from Africa to America. Over 17,000 enslaved Africans per year were sold to the Caribbean (Zantop, Colonial Fantasies, 38).

48. Ibid., 19. Cuba provides numerous examples of how, particularly in the eighteenth and nineteenth century, German capital was regularly invested in the Americas. Since slavery in Cuba was only abolished in 1886 , German investments on the islands usually included the exploitation of slave labor, and German merchants continued to be actively involved in the trade in enslaved African workers. Tellingly, the German sugar export association (Deutscher Zuckerexportverein) existed until 1886, the very year when slavery was finally abolished in Cuba (Álvarez Estévez and Guzmán, Alemanes en Cuba, 30). See in this context also the study by Schulte Beerbühl and Frey on the cigar merchant Uppmann from Bielefeld, "Die H. Upmann Zigarre."

49. Wallenta, "Die Handelsgenies," 11-15.

50. Kluger, The Wealthy Fuggers, 7, 13.

51. Denzer, Die Konquista, 26.

52. See, for example Arciniegas, Germans in the Conquest.

53. Brog, In Defense of Faith, 101.

54. Denzer, Die Konquista, 22.

55. Las Casas, An Account, 68. Las Casas engages in some wordplay in Spanish, irreproducible in English: Germans (alemánes) are paraphrased with the similar sounding term for animals (animales), he thus speaks about "these German, or beastly, tyrants." For more information on the German black legend, see Zantop, Colonial Fantasies, 24.

56. Las Casas, for instance, refers particularly to Alfinger whom he holds to be a Lutheran; therefore, he as a Catholic has to denounce him ("The German governor, this tyrant and also, we believe, heretic, for he neither heard mass nor allowed many others to hear it either, with other signs of Lutheranism that we found out)" (Las Casas, An Account, 66). However, Las Casas originally did not "single out" the Germans, since he stated that they were just as bad as other conquerors:

[S]ince they entered into these lands [...] they have sent many ships loaded and shipped with Indians over the sea to be sold for slaves in Santa Marta and on the island of Hispaniola and Jamaica and the island of San Juan. [...] There is no reason to make all these Indians into slaves save perverse, blind, and stubborn willfulness, in obedience to the insatiable greed for gold and those exceedingly avaricious tyrants, like all others in all the Indies have always done, taking and sizing those lambs and sheep from their homes and taking alike their women and children in the cruel and 
nefarious ways that we have spoken of, and shackling them in the king's irons to sell them for slaves. (Las Casas, An Account, 68)

57. In the appendix to her biographies, titled "Otros conquistadores de segundo y tercer orden" (Other conquerors of second and third order), Acosta de Samper lists Juan Nicolás de Aleman without further detail than the note that he came to the Americas with Federmann and established himself in Tocaima, and that one of his daughters was later married to a Flame called Matías Esporquil (Acosta de Samper, Biografías de hombres ilustres ó notabes, 393).

58. Ibid., 83. My translation.

59. Ibid., 4. My translation. Emphasis in the original.

60. Ibid., 97. My translation.

61. Ibid. Acosta de Samper even depicts Federmann as physically attractive, which is an unusual perspective for a woman of her time: "He had a white and beautiful face, was of elevate stature, a red and thick beard and was skilled in all physical exercises."

62. The only account by a German conqueror himself is the Indianische Historia by Nicolas Federmann which he wrote about his trip in 1531. Federmann's main interest was to find gold, and he justified the submission of the Amerindians through the endeavor to bring them the Christian faith and baptize them and to either make them become his "friends" and be exploited as guides and carriers or destroy their lands, capture them, enslave them, and rob their children and wives. In his introduction to the 1965 edition to Federmann's account, anthropologist and historian Juan Friede describes the practice of literally enslaving Amerindians as follows: "Above all prisoners were used as carriers. They were forged iron rings around the neck, which were then connected through a chain. This system allowed them to be used as baggage carriers and avoid their escape" (Friede, "Einführung," xvii). The German original reads: "Als Träger wurden vor allen Dingen auch Gefangene benutzt. Man schmiedete innen eiserne Ringe um den Hals, die dann durch eine Kette verbunden wurden. Dieses System erlaubte es, sie als Troßträger zu benutzen und ihre Flucht zu verhindern." Federmann, Indianische Historia, 23. Federmann's account also provides evidence of what Rubin has referred to as the "traffic in women" practiced between colonizing and colonized men. Rubin, "The Traffic in Women." At one instance, Federmann describes a "dwarf woman" he is given by a cacique (indigenous leader or noble man in Caribbean Taíno language). Federmann, Indianische Historia, 30.

63. The works by Zimmerer and Zeller, eds., Völkermord in Deutsch-Südwestafrika; Zimmerer and Peraudin, eds., German Colonialism; Zimmerer, ed., Verschweigen-Erinnern-Bewältigen and Von Windhoek bis Auschwitz?; Eckert, Kolonialismus; Conrad, Deutsche Kolonialgeschichte; Randeria, Römhild, and Conrad, Jenseits des Eurozentrismus, the recent (2016-2017) exhibition "German Colonialism: Fragments Past and Present" shown at the German History Museum in Berlin, etc., indicate a slow change of discourse. Numerous interventions and studies by People of Color have for decades been claiming a critical revision of Germany's colonial past and its present continuities, see Eggers et al., Mythen, Masken und Subjekte; Guitiérrez-Rodríguez and Steyerl, Spricht die Subalterne Deutsch?; Ha, Lauré al-Samarai, and Mysorekar, Re/Visionen. For an early account of German colonial history and the Welser, see also Opitz, Oguntoye, and Schultz, Showing Our Colors.

64. Zantop, Colonial Fantasies, 2.

65. Ibid., 16.

66. Ibid., 31-33.

67. Ibid., 209.

68. Federmann, Deutsche Konquistadoren, 7.

69. Ibid., 7-8.

70. Ibid., 9.

71. Ibid.

72. Kommunikation und Kaffee Augsburg quoted in Rauschnig, Gespräche mit Hitler, 61.

73. Federmann, Deutsche Konquistadoren, 23. My translation. 
74. Zantop, Colonial Fantasies, 10. According to Fernando Coronil, the concept of Occidentalism describes

the ensemble of representational practices that participate in the production of conceptions of the world, which (1) separate the world's components into bounded units; (2) disaggregate their relational histories; (3) turn difference into hierarchy; (4) naturalize these representations; and thus (5) intervene, however unwittingly, in the reproduction of existing asymmetrical power relations. (Coronil, "Beyond Occidentalism," 57)

Elaborating on this idea for the German context, in "Critical Whiteness", Gabriele Dietze has formulated the need for a self-critical examination of Western domination and its parameters in order to outclass naturalized hierarchical power asymmetries. Dietze transfers the self-critical stance of the concept of Critical Whiteness Studies to the specific German context as expressed in her concept "kritischer Okzidentalismus" [Critical Occidentalism], a "figure of thinking in a way critical of hegemony as a condition of possibility for a politics that seeks to avoid power asymmetries." Dietze, "Critical Whiteness," 239 (my translation).

75. The period of the brandenburgisch-afrikanische Kompagnie or the Berlin-based so-called Africa Conference (or Kongo Conference) of 1884 is also inadequately studied and taught.

76. See, for example, the Kreuzberg Museum in Berlin, which dedicates part of a room of its permanent exposition to the brandenburgisch-afrikanische Kompagnie as part of the city's history. In 2014, several subcultural Berlin institutions like the "post-migrant" theater Ballhaus Naunynstrasse and the art space "Savvy Contemporary" organized events memorizing the Berlin-based Africa conference of 1884 during which the European colonial powers divided the African continent among themselves. The project "Denkwerk" in Bremen, initiated by university professor Sabine Broeck, makes high-school students research the city's slavery past. Furthermore, there are numerous "postcolonial" city tours organized by initiatives like "Bielefeld postcolonial" or "Hamburg postcolonial."

77. Lieberknecht, "Der Sklavenhandel."

78. Namibian, Afro-German, and international activists are claiming financial, cultural (e.g., turning back a collection of skulls from the genocide on the Nama and Herrero), and intellectual (rewriting of history, canons, school curricula) reparation for the crimes committed in the colonies.

\section{Acknowledgements}

The author would like to thank a number of people for ongoing discussions about the topic of colonial entanglements, slavery, and Germany, especially Sabine Broeck, Manuela Boatcă, Claudia Rauhut, Carsten Junker, Gabriele Dietze, Alanna Lockward, Walter Mignolo, Roberto Zurbano, Anke Lucks, and Thomas Krüger, as well as Annika McPherson for accompanying me to the Welser museum in Augsburg. I am also grateful to the BMBF project "The Americas as Space of Entanglements" at the Center for InterAmerican Studies at the University of Bielefeld, which has supported my research abroad, part of which served as the basis for the current article, to the lbero-American Institute in Berlin for providing important sources and library space, and to the editors of this volume for the opportunity of being part of this necessary project.

\section{Disclosure statement}

No potential conflict of interest was reported by the author.

\section{Notes on contributor}

Julia Roth is a post-doctoral researcher at the research project "The Americas as Space of Entanglements" at the Center for InterAmerican Studies at Bielefeld University in Germany. Her research 
focuses on feminist and gender studies, decolonial thinking, postcolonial studies, critical race studies, global inequalities, transnational entanglements, and interdependencies, currently with a focus on the Caribbean. She has carried out research in Argentina, the United States, Nigeria, Puerto Rico, and Cuba. After studying American Studies, Hispanic Studies, and Political Science at Humboldt University Berlin, in London and Madrid, she was post-doctoral researcher at the network "desiguALdades.net. Interdependent Inequalities in Latin America" at Freie Universität Berlin and lecturer at the Gender Studies Department of Humboldt University and the Latin American Institute of Freie Universität. Alongside her academic work, she organizes cultural-political events.

\section{ORCID}

Julia Roth (D) http://orcid.org/0000-0003-4233-3527

\section{Bibliography}

Acosta de Samper, Soledad de. Biografías de hombres ilustres ó notabes. Relativos á la época del Descubrimiento, Conquista y Colonización de la parte de América denominada actualmente EE.UU. de Colombia. Bogotá: Imprenta de la Luz, 1883.

Álvarez Estévez, Rolando, and Marta Guzmán Pascual. Alemanes en Cuba (siglos XVII al XIX). Havana: Editorial de las Ciencias Sociales, 2004.

Arciniegas, Germán. Germans in the Conquest of America: A Sixteenth Century Venture. New York: The Macmillan Company, 1943 (first published under the title: Alemanes en la Conquista de América. Buenos Aires, 1941).

"Arroba." Merriam Webster Online Dictionary. Accessed 7 April 2017. www.merriam-webster.com/ dictionary/arroba.

"Arroba." Dictionary.com. Accessed 7 April 2017. www.dictionary.com/browse/arroba.

Brog, David. In Defense of Faith: The Judeo-Christian Idea and the Struggle for Humanity. New York: Encounter Books, 2010.

Conrad, Sebastian. Deutsche Kolonialgeschichte. München: C.H. Beck, 2012.

Coronil, Fernando. "Beyond Occidentalism: Toward Nonimperial Geohistorical Categories." Cultural Anthropology 11, no. 1 (1996): 51-87.

Denzer, Jörg. Die Konquista der Augsburger Welser-Gesellschaft in Südamerika 1528-1556. München: C.H. Beck, 2005.

Dietze, Gabriele. "Critical Whiteness und Kritischer Okzidentalismus. Zwei Figuren hegemonialer Selbstreflexion." In Weiss - Weißsein - Whiteness: Kritische Studien zu Gender und Rassismus, edited by Jana Hussmann-Kastein, Daniela Hrzán, and Gabriele Dietze, 232-250. Stuttgart: Peter Lang, 2006.

Eckert, Andreas. Kolonialismus. Frankfurt: Fischer, 2006.

Eggers, Maisha, Grada Kilomba, Peggy Piesche, et al., eds. Mythen, Masken und Subjekte. Kritische Weißseinsforschung in Deutschland. Münster: Unrast, 2005.

Federmann, Nicolaus. Indianische Historia. Mit einem Vorwort von Juan Friede. München: Klaus Renner, 1965.

Federmann, Arnold. Deutsche Konquistadoren und Südamerika. Berlin: Reimar Hobbing, 1938.

Friede, Juan. "Einführung." In Indianische Historia. Mit einem Vorwort von Juan Friede, edited by Nikolaus Fendermann, vii-xx. München: Klaus Renner, 1965.

Guitiérrez-Rodríguez, Encarnación, and Hito Steyerl, eds. Spricht die Subalterne Deutsch? Migration und Postkoloniale Kritik. Münster: Unrast, 2003.

$\mathrm{Ha}$, Kien Nghi, Nicola Lauré al-Samarai, and Sheila Mysorekar, eds. Re/Visionen. Postkoloniale Perspektiven von People of Color auf Rassismus, Kulturpolitik und Widerstand in Deutschland. Münster: Unrast, 2007.

Heyden, Ulrich van der. Rote Adler an Afrikas Küste. Die brandenburgisch-preußische Kolonie Großfriedrichsburg in Westafrika. Berlin: Selignow, 2001. 
Kluger, Martin. The Wealthy Fuggers. Pomp and Power of the German Medici in Golden Augsburg of the Renaissance. Augsburg: Regio Augsburg Tourismus GmbH, 2016.

Kommunikation und Kaffee Augsburg. "Welser und Fugger und der deutsche Imperialismus." KoKa, Kommunikation und Kaffee, 2014. Accessed 20 January 2016. http://koka-augsburg.net/welserfugger/.

Las Casas, Fray Bartolomé de. An Account, Much Abbreviated, of The Destruction of the Indies [1524], edited with an introduction by Franklin W. Knight and translated by Andrew Hurley. Cambridge: Hackett, 2003.

Lieberknecht, Wolfgang. "Eingebrannt: C AB C (Churfürstlich-Afrikanisch-Brandenburgische Compagnie). Der Sklavenhandel und die Deutschen." Journal Ethnologie 087/264 (2004). Accessed 20 January 2016. http://www.journal-ethnologie.de/Deutsch/Schwerpunktthemen/ Schwerpunktthemen_2004/Sklaverei/Eingebrannt:_C_AB_C/index.phtml.

Mintz, Sidney. Sweetness and Power. The Place of Sugar in Modern History. New York: Viking Press, 1985.

Opitz, May, Katharina Oguntoye, and Dagmar Schultz, eds. Showing Our Colors. Afro-German Women Speak Out. Amherst: University of Massachusetts Press, 1992.

Ortíz, Fernando. Contrapunteo Cubano del tabaco y el azúcar. Havana: Editorial de Ciencias Sociales, 1983.

Otte, Enrique. "Die Welser in Santo Domingo [1962]." In Von Bankiers und Kaufleuten, Räten, Reedern und Piraten, Hintermännern und Strohmännern. Aufsätze zur atlantischen Expansion Spaniens, edited by Günter Vollmer and Horst Pietschmann, 117-159. Stuttgart: Franz Steiner, 2004.

Otte, Enrique. "Jakob und Hans Cromberger und Lazarus Nürnbger, die Begründer des deutschen Amerikahandels [1963]." In Von Bankiers und Kaufleuten, Räten, Reedern und Piraten, Hintermännern und Strohmännern. Aufsätze zur atlantischen Expansion Spaniens, edited by Günter Vollmer and Horst Pietschmann, 161-197. Stuttgart: Franz Steiner, 2004.

Randeria, Shalini, Sebastian Conrad, and Regina Römhild, eds. Jenseits des Eurozentrismus. Postkoloniale Perspektiven in den Geschichts- und Kulturwissenschaften. Frankfurt/Main: Campus, 2014.

Randeria, Shalini. "Entangled Histories of Uneven Modernities: Civil Society, Caste Solidarities and Legal Pluralism in Post-colonial India." In Civil Society - Berlin Perspectives, edited by John Keane, 213-242. New York: Berghahn, 2006.

Rauschnig, Hermann. Gespräche mit Hitler. Zürich: Europa, 1940.

Rubin, Gayle. "The Traffic in Women: Notes on the 'Political Economy' of Sex." In Toward an Anthropology of Women, edited by Rayna Reiter, 157-210. New York: Monthly Review Press, 1975.

Schmitt, Eberhard. Konquista als Konzernpolitik: Die Welser-Statthalterschaft über Venezuela 15281556. Bamberg: Kleine Beiträge zur europäischen Überseegeschichte, 1992.

Schulte Beerbühl, Margit, and Barbara Frey. "Die H. Upmann Zigarre - Der Bielefelder Hermann Dietrich Upmann und die Schaffung einer Weltmarke." In Forschen - Verstehen - Vermitteln. Festschrift zum 100. Jahrestag des Historischen Vereins für die Grafschaft Ravensberg, edited by Johannes Altenberend and Reinhard Vogelsang, 243-279. Bielefeld: Verlag für Regionalgeschichte, 2015.

Simmer, Götz. Gold und Sklaven: Die Provinz Venezuela während der Welser-Verwaltung (1528-1556). Berlin: Wissenschaft und Technik, 2000.

Tatendrang, ed. Fugger und Welser. Museum, Historie, Marketing. Augsburg: Liquid Agentur für Gestaltung, 2015.

Wallenta, Wolfgang. "Die Handelsgenies. Die Fugger und Welser in Augsburg." In Fugger und Welser. Museum, Historie, Marketing, edited by Tatendrang and Das Magazin, 11-15. Augsburg: Liquid Agentur für Gestaltung, 2015.

Werner, Theodor Gustav. Das Kupferhüttenwerk des Hans Tetzel aus Nürnberg auf Kuba (1545-1571) und seine Finanzierung durch europäisches Finanzkapital. Wiesbaden: Franz Steiner, 1961.

Zantop, Susanne. Colonial Fantasies: Conquest, Family, and Nation in Precolonial Germany, 1770-1870. Durham, NC: Duke University Press, 1997.

Zimmerer, Jürgen, ed. Verschweigen-Erinnern-Bewältigen. Vergangenheitspolitik in globaler Perspektive. Special Volume of Comparativ 14, no. 5/6 (2004). 
Zimmerer, Jürgen, and Michael Perraudin, eds. German Colonialism and National Identity. New York: Routledge, 2011.

Zimmerer, Jürgen, ed. Von Windhuk nach Auschwitz? Beiträge zum Verhältnis von Kolonialismus und Holocaust. Münster: LIT, 2011.

Zimmerer, Jürgen, and Joachim Zeller, eds. Völkermord in Deutsch-Südwestafrika. Der Kolonialkrieg in Namibia (1904-1908) und die Folgen. Berlin: Christoph Links, 2003.

Zeuske, Michael. Handbuch Geschichte der Sklaverei. Eine Globalgeschichte von den Anfängen bis zur Gegenwart. Berlin: de Gruyter, 2013. 